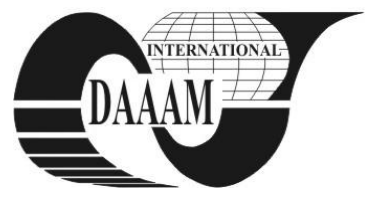

\title{
THE ONLINE ENVIRONMENT- A VIABLE ENTREPRENEURSHIP SOLUTION FOR THE ROMANIAN ECONOMICS STUDENTS- A MARKETING RESEARCH
}

\author{
NEGRICEA, C[ostel] I[liuta]; EDU, T[udor] M[ihai] \& IVANESCU, I[uliu] M[arin]
}

\begin{abstract}
The aim of this article is to identify, based on market research, the young people's perception of the online environment as a communication and business environment. The study emphasizes the way in which the future Romanian Economics graduates consider the online environment as a facilitator of new entrepreneurship initiatives. The study presents also some particular features of online services used by the young people and online marketing tools used by the Romanian organisations to target them
\end{abstract}

Key words: online entrepreneurship, student, online marketing

\section{INTRODUCTION}

The current economic difficulties perceived as repeated wavesat global level, generate very different effects within the markets, and on economic and social life components. The impact is absorbed by the social and demographic structures; however, the impact on students is higher, being amplified by the effect on family groups and other community groups; this finally leads to changes of the system of values and perception of future career and social development.

It's not by chance that we take into consideration the online environment as a development environment for communication, information and vocational training of young people, and entrepreneurship initiatives. According to the research, over $95 \%$ of Romanian students use the Internet on a current basis, and have a good knowledge of Web services and applications. The online environment is the main young people's communication and information means; it represents the "link" between the individuals of a social group, the universe where the student seeks present and future references at every stage and at every moment of his/her professional and personal development.

\section{OBJECTIVES AND METODOLOGY}

The market research was performed based on primary information sources; it was aimed at identifying the extent to which the Romanian young people, who have graduated from an Economics university, envisage the use of Internet as a very useful and efficient means for developing their own future business. Also, the study had in view the identification of the most important entrepreneurship online activities and perception of online services and tools used by the Romanian organisations.

The research results could determine the increase of public and private organisations' interest in encouraging the young people's entrepreneurial initiative. It also reveals some characteristics of this market segment. The conclusions of the study could be the starting point for designing a more detailed research.

The secondary data already exist (Chaffey \& Smith, 2008). They were collected within research studies performed at a prior date (Negricea, 2010). The previous research purposes had in view the online customer behaviour mainly (Grgona et al., 2008), analysed by age groups, and the impact of the new IT\&C technologies on the young people (Cosoi et al., 2009). The secondary data are very useful, because they can provide meaningful insight on various matters (Negricea, 2006). The conclusions drawn after the analysis of the secondary data can be sufficient for the researcher. If they are not sufficient, they can represent a starting point for further research studies, such as a focus group, an in-depth interview or a survey.

\section{RESEARCH RESULTS}

The research was based on a sample of 385 students within the Economics faculties of Bucharest, aged between 18 and 24 years. The gathering and analysis of data were performed between April 15, 2011 and July 15, 2011. Online and offline questionnaires were sent out in view of fulfilling the research objectives.

According to the research, most of the students $(85.7 \%)$ access the Internet from home, several times a day, by sessions between 1 and 3 hours.

Due to its features, the online environment is the main information tool, followed by television and media. The main category of accessed information is entertainment; the second being educational information.

Its characteristic as the main information environment, compared to television, library or other offline information sources, may be due to the easiness of finding necessary information, as well as availability of information, time saving and low costs.

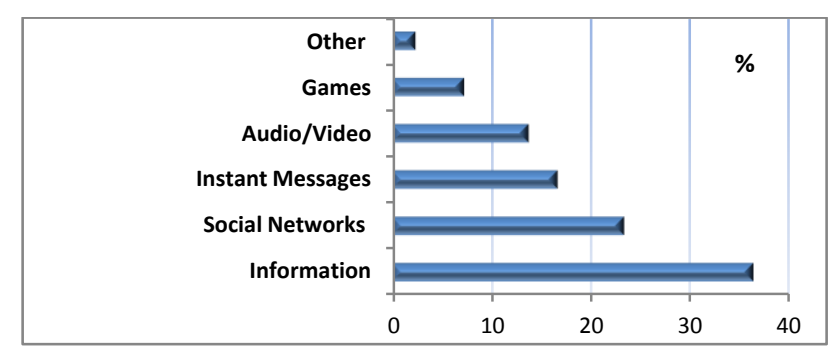

Fig. 1. Specific online student activities

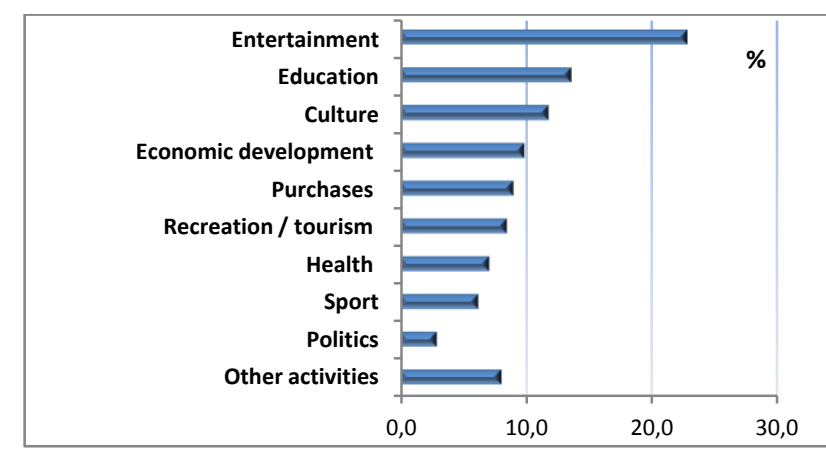

Fig. 2. Categories of information accessed by Romanian students 
As a comparison with the latest study performed two years ago, we can say that the online environment is used even more as a socialising environment, and less as an information environment, which is due to the latest development of social networks.

According to the research, the reasons for using online services are speed (43\%), 24 hour availability and easy access $(24,4 \%)$ of these services. Lack of security $(23,2 \%)$, lack of necessary / free information $(21,2 \%)$ and the huge amount of unstructured data $(20,4 \%)$ are the main shortcomings of the online environment, in the young people's opinion.

The online organisations benefit from a better image in the eyes of young people, as they communicate online easily and efficiently, with the market in general and with the segment of customers aged between 18 and 24 .

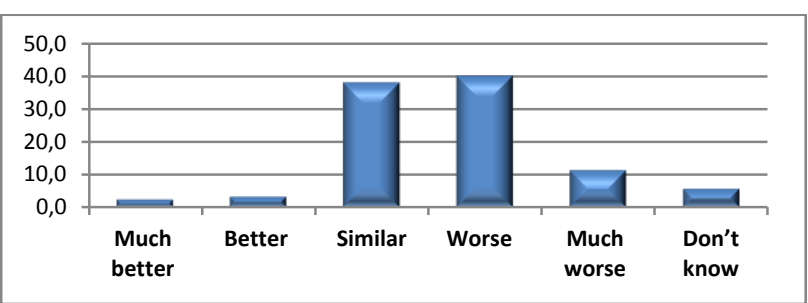

Fig. 3. Romanian students' opinion on quality of Romanian web sites as compared to foreign sites

According to the research results, the students make aquality difference between the Romanian web sites and the foreign sites. As a conclusion, the Romanian sites need to be improved: a rather high percentage of young people $(40,5 \%)$ considers that the structure, content and services offered by Romanian sites are below the quality level of the foreign web sites.

After having analysed the Romanian Economics students' opinion on the online environment mainly associated to the „.ro" domains, we emphasise below the young people's confidence in this environment as a development environment for the new entrepreneurship initiatives.

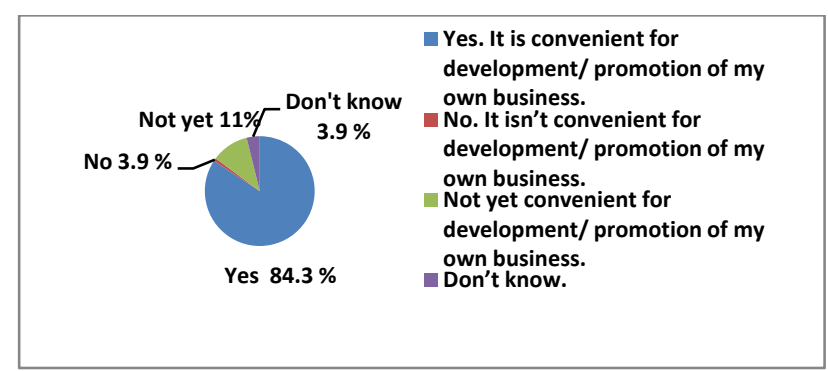

Fig. 4. Young people's perception of the online environment as a business environment

Most of the questioned students have asserted that the online environment is convenient for development/ promotion of one's own business.

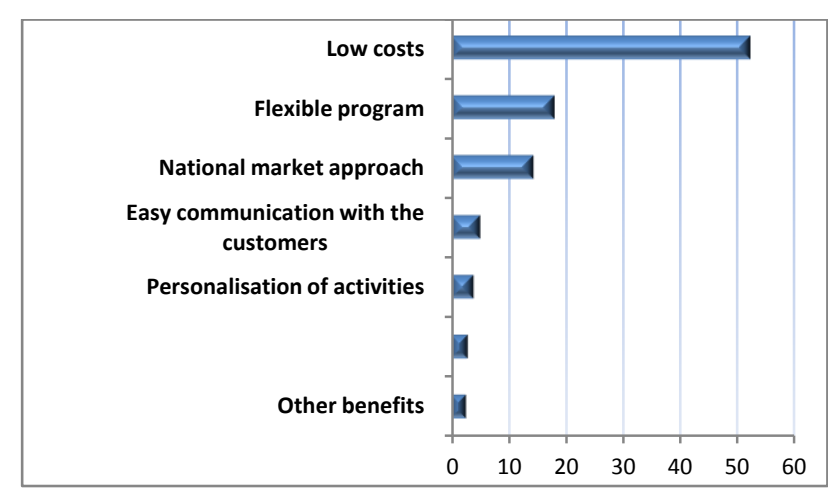

Fig. 5. Main benefits of online business development
The most frequent activities that the young people would develop online were: creation of an online commercial site, development of an economic service site (various domains have been mentioned, among which marketing consultancy and PR, online market research, transactions, mediation) and development of an information site. Beside these activities, apart of the respondents expressed their interest in online and offline integrated entrepreneurial activities.

With regards to starting a new business, the online environment benefits mentioned by respondents, as compared to the traditional environment are the following: low initial investment, the possibility to approach target markets in various regions of the country with minimum efforts and flexibility of business start-up.

\section{CONCLUSION}

According to the research study results, one can state that the students consider the online environment as being convenient for new entrepreneurial initiative development. The main advantage is related to the low costs that are needed for the business start-up. As a limitation of our endeavour we could mention the focus on just the Economics students. We consider this approach to be a suitable starting point for a comprehensive view of the Romanian students on the respective topic. For the future we plan to broaden our investigation on students pursuing other areas of education, such as Engineering, Foreign Languages and Law.

The young people's confidence in the online environment supports the future development of this environment and online marketing tools. This fact may be encouraged by a stable legal framework that would provide the premises for a harmonious development, creation of good practice codes and a useroriented responsible organizational behaviour.

\section{REFERENCES}

Chaffey, D., Smith, PR., (2008). eMarketingXcellence, Planning and optimizing your digital marketing, $3^{\text {rd }}$ Ed., Butterworth-Heinemann, ISBN 978-0-7506-8945-8, Oxford,UK

Cosoi, C. M. \&Anghel, L. D. (2009)..Assessing the Evolution of Virtual Marketing Activities Targeting Children, Annals of DAAAM for 2009 \& Proceedings of the 20th International DAAAM Symposium, 25-28th November 2009, Vienna, Austria, ISSN 1726-9679, ISBN 978-3-901509-70-4, Katalinic, B. (Ed.), pp. 0173-0174, Published by DAAAM International Vienna, Vienna

Grgona, J.; Andrlic, B. \& Del Vechio, M. (2008)..Influence of Internet on Consumer Behaviour in Tourism, Annals of DAAAM for 2008 \& Proceedings of the 19th International DAAAM Symposium, 22-25th October 2008, Trnava, Slovakia, ISSN 1726-9679, ISBN 978-3-901509-68-1, Katalinic, B. (Ed.), pp. 0531-0532, Published by DAAAM International Vienna, Vienna

Negricea, I.C., (2010). Online marketing strategies - Successful solutions for development and implementation of online marketing applications in the activity of organisations, Universitară, Bucharest, 2010, ISBN 978-973-749-967-7

Negricea, I.C., (2006). The challenges of the World Economy Cohesion Factor-The INTERNET: world reorganization, vulnerabilities, discrepancies and power discernment, Romanian Economic and Business Review, Vol. 1, Nr. 1, pg.59-66, Published by Pro Universitaria, Bucharest 2006, ISSN 1842-2497 